\title{
Helminth allergens, parasite-specific IgE, and its protective role in human immunity
}

\section{Colin Matthew Fitzsimmons ${ }^{1 \dagger}{ }^{\dagger}$, Franco Harald Falcone ${ }^{2 *}$ and David William Dunne ${ }^{1}$}

${ }^{1}$ Department of Pathology, University of Cambridge, Cambridge, UK

2 School of Pharmacy, University of Nottingham, Nottingham, UK

\section{Edited by:}

Annette Kuehn, Centre de Recherche Public de la Santé, Luxembourg

\section{Reviewed by:}

Tracey Lamb, Emory University School of Medicine, USA

Adriano Mari, Centri Associati di Allergologia Molecolare, Italy

\section{${ }^{*}$ Correspondence:}

Franco Harald Falcone, Division of Molecular and Cellular Science, School of Pharmacy, University of Nottingham, Boots Science Building, Science Road, Nottingham NG7 2RD, UK

e-mail: franco.falcone@

notttingham.ac.uk

${ }^{+}$Colin Matthew Fitzsimmons and Franco Harald Falcone have contributed equally to this work.
The Th2 immune response, culminating in eosinophilia and IgE production, is not only characteristic of allergy but also of infection by parasitic worms (helminths). Anti-parasite $\lg E$ has been associated with immunity against a range of helminth infections and many believe that IgE and its receptors evolved to help counter metazoan parasites. Allergens (IgE-antigens) are present in only a small minority of protein families and known lgE targets in helminths belong to these same families (e.g., EF-hand proteins, tropomyosin, and PR-1 proteins). During some helminth infection, especially with the well adapted hookworm, the Th2 response is moderated by parasite-expressed molecules. This has been associated with reduced allergy in helminth endemic areas and worm infection or products have been proposed as treatments for allergic conditions. However, some infections (especially Ascaris) are associated with increased allergy and this has been linked to cross-reactivity between worm proteins (e.g., tropomyosins) and highly similar molecules in dust-mites and insects. The overlap between allergy and helminth infection is best illustrated in Anisakis simplex, a nematode that when consumed in under-cooked fish can be both an infective helminth and a food allergen. Nearly 20 molecular allergens have been isolated from this species, including tropomyosin (Ani s 3 ) and the EF-hand protein, Ani s troponin. In this review, we highlight aspects of the biology and biochemistry of helminths that may have influenced the evolution of the lgE response. We compare dominant lgE-antigens in worms with clinically important environmental allergens and suggest that arrays of such molecules will provide important information on anti-worm immunity as well as allergy.

Keywords: helminth, allergen, Schistosoma mansoni, protective role, IgE

\section{THE IgE RESPONSE IS A PHYSIOLOGICAL IMMUNE RESPONSE TO HELMINTH INFECTION}

The parallels between allergy and the immune response to parasitic worms (helminths) have been noted for some time. Unlike most other inflammatory/infectious conditions, allergy, and helminths induce strongly Th2-skewed responses associated with cytokines such as IL-4, IL-5, and IL-13, with mastocytosis, eosinophilia, and antibody class-switching to produce IgE [reviewed in Ref. (1)]. This normally rare, tightly controlled antibody isotype is greatly elevated in helminth infection. It is widely accepted that IgE, its receptors and distinctive cellular responses did not evolve to target harmless molecules occurring in plant pollen, dust-mites, or animal dander. Instead many believe that the $\operatorname{IgE}$ axis evolved to counter metazoan parasites (worms and parasitic arthropods) which are too large to be phagocytosed, and that allergy is a misdirected anti-parasite response in hypersensitive people (2). The symptoms of allergic responses; lachrymation, rhinitis, coughing, increased mucus production, and itching in response to histamine release are all responses likely to dislodge, trap, or flush out large parasites from skin or mucosa, e.g., by scratching.

There are however critical differences between the two conditions. Allergy occurs in people with atopy; defined as "a genetic predisposition toward the development of immediate hypersensitivity reactions against common environmental antigens" (3). It is a polygenic disorder linked to polymorphisms in genes of cytokine, cytokine receptors, and transcription factors associated with Th2 immune responses and with the expression of IgE and its receptors (4-7). In contrast, the elevated Th2 cytokines, IgE and eosinophilia during helminth infection are normal physiological responses to these pathogens. Furthermore, helminths actively moderate the inflammatory $\mathrm{Th} 2$ response of the host, inducing regulatory $\mathrm{T}$ and $\mathrm{B}$ cells, alternatively activated macrophages and production of immunoregulatory cytokines, such as IL-10 and TGFß, as well as IgG4 antibodies that counteract IgE [reviewed in Ref. (8)].

Recently Medzhitov and colleagues (9) re-appraised the toxin hypothesis of allergy (10), proposing that the IgE-mediated hypersensitivity response evolved to counter venoms and other noxious substances rather than macro-parasites. They argued that (1) immediate hypersensitivity is very rapid and worms are slow, (2) IgE is not required for worm immunity in mice, and (3) allergens do not have any obvious relationship with worms. Instead they proposed that it is toxins and venoms that need to be rapidly neutralized and that unpleasant allergic symptoms provoke toxinavoidance behavior. This "toxin hypothesis" of allergy can in fact be traced back to the original discovery of anaphylaxis by Portier and Richet (11) [reviewed in (12)]. However, we would argue that (1) defense against invading helminth larvae also requires very fast responses - as elegantly demonstrated in the film of 
Schistosoma mansoni cercariae penetrating and moving rapidly through skin tissue (13). Most recently, work by Obata-Ninomiya in Karasuyama's group (14) has demonstrated the importance of IgE (via ablation of the high affinity receptor) on basophils (but not mast cells) in trapping invading Nippostrongylus brasiliensis larvae in the skin of mice.

While it can be shown that IgE is not strictly necessary for anti-worm immunity in mice [argument (2) above], it needs to be stressed that there are other immunity mechanisms operating as well; $\operatorname{IgE}$ is a late mammalian additional mechanism to the Th2-mediated mechanisms of lower vertebrates (which are nonetheless still present in mammals), thus IgE-immunity is not the only mechanism of immunity against metazoan parasites available to mammals. This is exemplified by the occurrence of Th2-like immune responses to helminth infection in avian hosts in the absence of IgE (15). Finally [argument (3) above], we propose here that nearly all known allergens have equivalents (of widely varying structure) in metazoan parasites.

Most of the evidence relating IgE to anti-helminth immunity comes from epidemiological data. In a number of studies on human schistosomiasis, levels of anti-parasite IgE have been correlated with resistance to infection (16-22). Anti-parasite IgE responses have also been associated with immunity in human infections with hookworms $(23,24)$, Trichuris (25), and Ascaris $(26,27)$. Human experimental infection with a single, low dose of Necator americanus larvae in the context of helminth immunotherapy trials has shown that peripheral blood basophils become sensitized to parasitic allergens within 6 weeks of exposure, and remain fully responsive to stimulation with hookworm allergens years after this single infection (28). Thus, it appears that helminths are indeed powerful inducers of an IgE response, but how does this response relate to allergy?

\section{EFFECTS OF HELMINTHS ON ALLERGY}

Paradoxically, the global increase in allergy especially in urban areas (29) has led researchers to propose a modified hygiene hypothesis in which the decline in helminth infections is associated with an increase in allergic diseases (30). A number of studies show that communities with helminth infections have reduced rates of allergy (31-33) and the evidence that people with hookworm have less asthma (34-36) has inspired researchers to use experimental infections on asthma patients (37). It is proposed that the active suppression of Th2 responses by helminths has a bystander effect on concurrent allergic responses [reviewed in Ref. (8)]. In a study on Gabonese children, van den Biggelaar et al. (31) showed that the increased IL-10 levels induced by schistosome infection were negatively correlated with dust-mite sensitivity. The other side of these phenomena is that anti-helminth treatment programs risk increased rates of allergic disease and this has already been demonstrated in a number of intervention studies (38-40).

Under some circumstances helminth infection can actually increase prevalence of atopic disease and asthma (41, 42). A metaanalysis of 30 clinical studies on intestinal nematodes, concluded that while hookworm reduced the incidence of asthma, Ascaris lumbricoides increased the risk (34). It is likely that cross-reactivity between Ascaris and environmental allergens is involved.
The concept of cross-reactivity between helminth and environmental allergens is central to this review. We suggest that most if not all environmental allergens can be related to helminth counterparts and that the IgE response against these allergens is associated with host protection.

\section{ARE ALL ALLERGENS PROTEINS WITH HOMOLOGS IN METAZOAN PARASITES?}

Work in the allergy field has shown that very few protein families contain allergens (43) and importantly, the molecules targeted by IgE in helminths appear to be in these known allergen families (see Tables 1 and 2). Certain domains are highly represented in the list of known molecular allergens with the 10 most common allergen families containing approximately $40 \%$ of all know allergens. In the following section, we review the relationship between known helminth allergens and the structural allergen classification in the allergen database AllFam (http: //www.meduniwien.ac.at/allergens/allfam).

For example, the muscle protein tropomyosin (AllFam code AF054) is an important IgE target in a number of nematode infections; Onchocerca volvulus (76, 77); Ascaris lumbricoides (78); Anisakis simplex [Ani s 3, (46)]; and tropomyosin from the blood fluke Schistosoma mansoni is also a human IgE antigen (Fitzsimmons, unpublished data). Tropomyosin is highly conserved across many invertebrates and is responsible for much of the IgE cross-reactivity between Ascaris and dust-mites (63). Cockroach tropomyosin is a major allergen (Bla g 7 ) that also shows strong IgE cross-reactivity with the highly similar Ascaris molecule (78). Santiago and co-authors (77) showed that tropomyosin from filarial nematodes is recognized by $\operatorname{IgE}$ against dust-mite tropomyosin (Der p 10), which can be absorbed completely using the nematode molecule. More importantly, they showed that the IgE response to Der $\mathrm{p} 10$ was stronger in filarial-infected than in uninfected individuals.

Paramyosin is another allergen family (AF100) from invertebrate muscle targeted in IgE responses against Schistosoma japonicum (20), Ascaris lumbricoides (79), Anisakis simplex [Ani s 2 (45, 80)], and Onchocerca volvulus (81). There is evidence that Ascaris paramyosin shows IgE cross-reactivity with the tropical dust-mite paramyosin and allergen Blo t 11 (79). Cross-reactivity between helminths and environmental allergens has clear implications. Not only may some helminth infections increase sensitivity to mites and insects, but also high degrees of homology between parasite and allergic orthologs could lead to false diagnosis. Human helminth infections are not restricted to tropical regions (82). Ani s 2 and Ani s 3 are thought to be responsible for much of the cross-reactivity between Anisakis and other invertebrate species (83).

The helminth venom-allergen-like (VAL) proteins are another family targeted by IgE. Hookworms secrete a VAL-like molecule, called Ancylostoma Secreted Protein-2 (ASP-2), which was shown to be a potent IgE antigen in human studies in China and Brazil $(24,84)$. An IgE response to this molecule has been correlated with immunity (24). ASP-2 belongs to the Pathogen related-1 (PR1) allergen family (AF044) characterized by the presence of the SCP/TAPS domain (Pfam, PF00188). The family contains group 3 and 5 insect venom allergens and VAL molecules from filarial 
Table 1 | Summary of helminthic allergens.

\begin{tabular}{|c|c|c|c|c|c|c|c|}
\hline $\begin{array}{l}\text { Helminth } \\
\text { allergen }\end{array}$ & Common name & $\begin{array}{l}\text { Gene ontology } \\
\text { (biological } \\
\text { process) }\end{array}$ & $\begin{array}{l}\text { Related } \\
\text { common } \\
\text { allergen }\end{array}$ & $\begin{array}{l}\text { Conserved } \\
\text { domains }\end{array}$ & $\begin{array}{l}\text { UniProt } \\
\text { accession } \\
\text { number }\end{array}$ & AllFam & Reference \\
\hline Ani s 1 & $\begin{array}{l}\text { Serine protease } \\
\text { inhibitor (Kunitz type) }\end{array}$ & $\begin{array}{l}\text { Serine protease } \\
\text { inhibitor }\end{array}$ & Aprotinin & $\begin{array}{l}\text { BPTI/Kunitz family } \\
\text { of serine protease } \\
\text { inhibitor cd00109 }\end{array}$ & L7V3O3 & AF003 & Moneo et al. (44) \\
\hline Ani s 3 & Tropomyosin & Troponin T binding & Panallergen & $\begin{array}{l}\text { Tropomyosin } \\
\text { PF00261 }\end{array}$ & Q9NAS5 & AF054 & Asturias et al. (46) \\
\hline Ani s 4 & Cystatin & $\begin{array}{l}\text { Cysteine type } \\
\text { endoprotein type } \\
\text { inhibitor }\end{array}$ & $\begin{array}{l}\text { Minor cat allergen } \\
\text { (Fel d3) }\end{array}$ & $\begin{array}{l}\text { Cystatin-like } \\
\text { domain cd00042 }\end{array}$ & Q14QT4 & AF005 & Moneo et al. (47) \\
\hline Ani s 6 & $\begin{array}{l}\text { Trypsin inhibitor like } \\
\text { cysteine rich domain }\end{array}$ & $\begin{array}{l}\text { Trypsin inhibitor like } \\
\text { cysteine rich domain }\end{array}$ & $\begin{array}{l}\text { Minor latex } \\
\text { allergen (Hev b } \\
\text { SPI) }\end{array}$ & $\begin{array}{l}\text { Trypsin inhibitor } \\
\text { like cysteine rich } \\
\text { domain PF01826 }\end{array}$ & A1IKL3 & $\mathrm{n} / \mathrm{a}$ & Kobayashi et al. (48) \\
\hline Ani s 7 & $\mathrm{n} / \mathrm{a}$ & Unknown & Unknown & None & A9XBJ8 & $\mathrm{n} / \mathrm{a}$ & Rodríguez et al. (49) \\
\hline Ani s 8 & SXP/RAL-2 & Unknown & Unknown & DUF148 PF02520 & A7M6S9 & AF137 & Kobayashi et al. (48) \\
\hline Ani s 9 & SXP/RAL-2 & Unknown & $\begin{array}{l}\text { Unknown (As14 } \\
\text { ascaris allergen) }\end{array}$ & DUF148 PF02520 & $\mathrm{B} 2 \times \mathrm{CP} 1$ & AF137 & $\begin{array}{l}\text { Rodriguez-Perez } \\
\text { et al. (50) }\end{array}$ \\
\hline Ani s 10 & Unknown & Unknown & Unknown & Unknown & D2K835 & $\mathrm{n} / \mathrm{a}$ & Caballero et al. (51) \\
\hline Ani s Cyt B & Cytochrome $b$ & $\begin{array}{l}\text { Aerobic electron } \\
\text { transport chain }\end{array}$ & Unknown & $\begin{array}{l}\text { Cytochrome } b(\mathrm{~N}- \\
\text { terminus)/b6/petB } \\
\text { cd00284 }\end{array}$ & $\mathrm{Q} 1 \times 6 \mathrm{~L} 0$ & $\mathrm{n} / \mathrm{a}$ & López and Pardo (53) \\
\hline Ani s FBPP & $\begin{array}{l}\text { Fructose } \\
\text { 1,6-bisphosphatase }\end{array}$ & Phosphatase activity & Unknown & $\mathrm{n} / \mathrm{a}$ & $\mathrm{n} / \mathrm{a}$ & $\mathrm{n} / \mathrm{a}$ & López and Pardo (53) \\
\hline $\begin{array}{l}\text { Ani s } \\
\text { NADHDS4L }\end{array}$ & $\begin{array}{l}\text { NADH dehydrogenase } \\
\text { subunit } 4 \mathrm{~L}\end{array}$ & NADH dehydrogenase & Unknown & ND4L cl10160 & $\mathrm{Q} 1 \times 6 \mathrm{~K} 2$ & $\mathrm{n} / \mathrm{a}$ & López and Pardo (53) \\
\hline $\begin{array}{l}\text { Ani s } \\
\text { NARaS }\end{array}$ & $\begin{array}{l}\text { Nicotinic acetylcholine } \\
\text { receptor alpha-subunit }\end{array}$ & $\begin{array}{l}\text { Unknown (nicotinic } \\
\text { acetylcholine receptor) }\end{array}$ & Unknown & $\mathrm{n} / \mathrm{a}$ & $\mathrm{n} / \mathrm{a}$ & $\mathrm{n} / \mathrm{a}$ & López and Pardo (53) \\
\hline Ani s PEPB & $\begin{array}{l}\text { (Phosphatidyl- } \\
\text { ethanolamine-binding } \\
\text { Protein) }\end{array}$ & $\begin{array}{l}\text { Unknown } \\
\text { (phosphatidyl- } \\
\text { ethanolamine-binding) }\end{array}$ & Unknown & $\mathrm{n} / \mathrm{a}$ & $\mathrm{n} / \mathrm{a}$ & $\mathrm{n} / \mathrm{a}$ & López and Pardo (53) \\
\hline $\begin{array}{l}\text { Ani s } \\
\text { Troponin }\end{array}$ & Troponin C & Calcium ion binding & $\begin{array}{l}\text { German } \\
\text { cockroach } \\
\text { allergen (Bla g 6) }\end{array}$ & $\begin{array}{l}\text { EF-hand } \mathrm{Ca}^{2+} \\
\text { binding motif } \\
\text { PF00036 }\end{array}$ & Q9U3U5 & AF007 & Arrieta et al. (54) \\
\hline
\end{tabular}


Table 1 | Continued

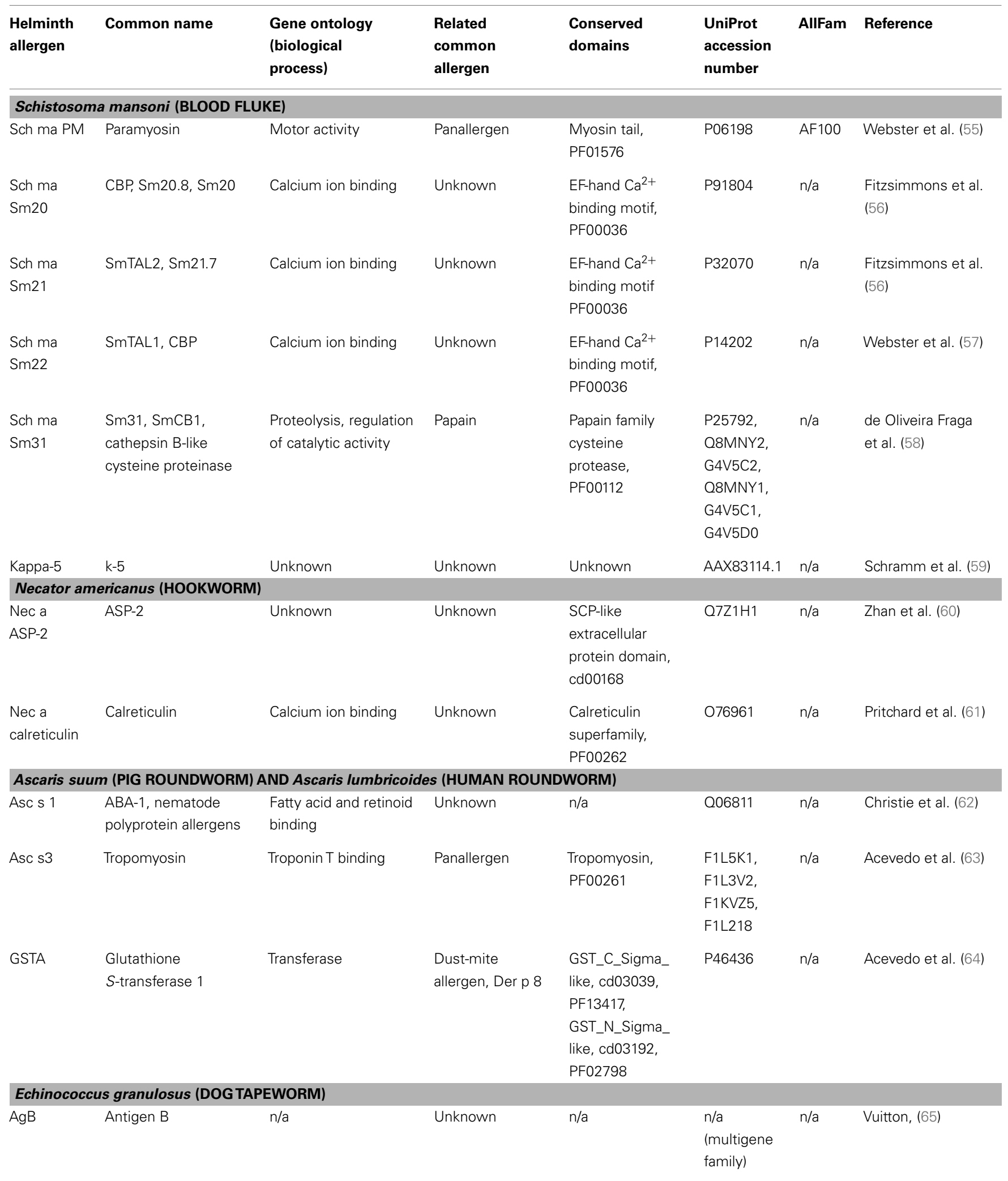


Table 1 | Continued

\begin{tabular}{|c|c|c|c|c|c|c|c|}
\hline $\begin{array}{l}\text { Helminth } \\
\text { allergen }\end{array}$ & Common name & $\begin{array}{l}\text { Gene ontology } \\
\text { (biological } \\
\text { process) }\end{array}$ & $\begin{array}{l}\text { Related } \\
\text { common } \\
\text { allergen }\end{array}$ & $\begin{array}{l}\text { Conserved } \\
\text { domains }\end{array}$ & $\begin{array}{l}\text { UniProt } \\
\text { accession } \\
\text { number }\end{array}$ & AllFam & Reference \\
\hline EA21 & Cyclophilin & Protein folding & $\begin{array}{l}\text { Malassezia furfur } \\
\text { allergen, Mal f } 6\end{array}$ & $\begin{array}{l}\text { Cyclophilin_ABH_ } \\
\text { like, cd01926 }\end{array}$ & P14088 & AF038 & Ortona et al. (67) \\
\hline HSP70 & Heat shock protein 70 & Response to stress & $\begin{array}{l}\text { Dust-mite } \\
\text { allergen Hsp70 }\end{array}$ & Hsp70 PF00012 & Q24789 & AF002 & Ortona et al. (68) \\
\hline $\begin{array}{l}\text { EF-1 } \\
\text { beta/delta }\end{array}$ & EF-1 & $\begin{array}{l}\text { Translation elongation } \\
\text { factor }\end{array}$ & Unknown & $\begin{array}{l}\text { Elongation factor } \\
1 \text { beta (EF1B) } \\
\text { guanine } \\
\text { nucleotide } \\
\text { exchange domain }\end{array}$ & $\begin{array}{l}\text { Q9U8D5, } \\
\text { Q9NGP3, } \\
\text { Q0PWC5 }\end{array}$ & $\mathrm{n} / \mathrm{a}$ & Ortona et al. (69) \\
\hline \multicolumn{8}{|c|}{ Brugia malayi (MALAYAN FILARIA) } \\
\hline Bru m 3 & Tropomyosin & Troponin T binding & Panallergen & $\begin{array}{l}\text { Tropomyosin, } \\
\text { PF00261 }\end{array}$ & A8NGJ2 & $\mathrm{n} / \mathrm{a}$ & Sereda et al. (70) \\
\hline Bru m 13 & $\begin{array}{l}\text { GST, glutathione } \\
\text { S-transferase }\end{array}$ & Metabolic process & $\begin{array}{l}\text { House dust-mite } \\
\text { allergen Der } p 8\end{array}$ & $\begin{array}{l}\text { GST_N family } \\
\text { cd03076, GST } \\
\text { C-terminal } \\
\text { domain family } \\
\text { cd03210 }\end{array}$ & $\begin{array}{l}\text { A8PTL9, } \\
\text { O02636 }\end{array}$ & $\mathrm{n} / \mathrm{a}$ & Rathaur et al. (71) \\
\hline $\begin{array}{l}\text { Bru m } \\
\text { Bm33 }\end{array}$ & $\begin{array}{l}\text { Aspartic protease } \\
\text { inhibitor, Bm33 }\end{array}$ & Unknown & Unknown & $\begin{array}{l}\text { Ascaris pepsin } \\
\text { inhibitor-3 (API3) } \\
\text { cl11634 }\end{array}$ & A8Q4E4 & $\mathrm{n} / \mathrm{a}$ & Krushna et al. (72) \\
\hline
\end{tabular}

This table was compiled mainly from data extracted from the Allergome database (73) in combination with published literature. Conserved domain annotation is from conserved domain database (CDD) (74) and Pfam (PF; DUF, domain of unknown function) (75). AllFam numbers (AF) are from the database of allergen families AllFam (43). As can be seen from this table, not all helminth allergens currently have related common (non-helminthic) allergens. For example, there are currently no known common environmental allergens structurally related to the nematode polyprotein allergens.

nematodes, Onchocerca volvulus (85), and Brugia malayi (86), as well as trematodes S. mansoni (87) and S. japonicum (88). Furthermore, the presence of VAL molecules is also predicted in tapeworms (89). One of the S. mansoni homologs (SmVAL4) has been recently shown to be an IgE antigen in mice (90), but requires confirmation in the natural human host.

The tegumental allergen-like (TAL) proteins are some of the most dominant IgE-antigens in S. mansoni and an IgE response to some members of the TAL family has been associated with resistance to re-infection with the parasite $(18,19,22)$. These molecules are EF-hand proteins (see Figure 1A), one of the biggest groups of molecular allergens (AF007). Other known allergenic helminth EF-hand proteins include Anisakis simplex troponin C (54) and the Fasciola calcium-binding protein, FgCaBP (91).

The glutathione $S$-transferase (GST) is another source of $\operatorname{IgE}$ cross-reactivity. GST of nematode species is targeted by IgE during infection (92). This enzyme is homologous with other members of the GST allergen family (AllFam, AF010) including major allergens in dust-mite (Der p 8) and cockroach (Bla g 5) as well as IgE-antigens in grass and fungi. GST from the filarial nematode Wuchereria bancrofti binds IgE against Bla g 5 (77).

Probably, the most potent helminth allergens are the nematodepolyprotein-antigens (NPA). These are large multimeric proteins that are cleaved into smaller fatty acid binding subunits (93) with functional but not structural similarity to the lipocalin allergens (AF015). The best characterized example is the ABA-1 protein from Ascaris species. Highly abundant in the body fluid of the adult worm, it provokes a strong IgE response in many infected individuals (93) and this has been associated with resistance to infection (27). The filarial nematode NPA termed gp15/400 has also been shown to be an IgE antigen (94). Interestingly, the non-NPA lipocalin-like fatty acid binding protein from filarial nematodes, BmA1.1, is an IgE antigen which can induce wheal and flare response in sensitized dogs (95).

While some of the Top 10 allergen families (tropomyosins, EFhand proteins, PR-1, and lipocalins) have members in helminth 
Table 2 | Examples of known allergens, compiled from AllFam (43) and published literature, illustrating that nearly all families of allergens in animals, plants, or fungi have corresponding allergens in helminths.

\begin{tabular}{|c|c|c|c|c|}
\hline Structural motif (AllFam Acc.) & Parasite allergens & Plant allergens & $\begin{array}{l}\text { Animal allergens } \\
\text { (non-helminth) }\end{array}$ & Fungal allergens \\
\hline Tropomyosin (AF054) & $\begin{array}{l}\text { Ani s 3, Asc s 3, Bru m 3, Onc } \\
\text { v 3, Onc o } 3\end{array}$ & - & Bla g 7, Blo t 10 & - \\
\hline Paramyosin (AF100) & Ani s 2, Sch j PM, Sch ma PM & - & Blo t 11, Der f 11, Der p 11 & - \\
\hline EF-hand (AF007) & Sm TAL1, Ani s Troponin & $\begin{array}{l}\text { Bet v 3, Bet v 4, Art v 5, } \\
\text { Par j 4, Phl p } 7\end{array}$ & $\begin{array}{l}\text { Cyp c 1, Gad m 1, Sal s 1, } \\
\text { Thu a } 1\end{array}$ & - \\
\hline $\begin{array}{l}\text { Glutathione S-transferase } \\
\text { (AF010) }\end{array}$ & $\begin{array}{l}\text { Wb GSTa, Bru m 13, Onc v 13, } \\
\text { Asc I 13, Asc s } 13\end{array}$ & Tri a GST & Bla g 5, Der p 8, Blo t 8 & Asp f GST, Pen c 24 \\
\hline Hsp70 (AF002) & Hsp70 (E. granulosus) & Cor a 10 & Der f HSP70 & Alt a 3, Cla h HSP70 \\
\hline Calreticulin (AF055) & Na Calreticulin & - & - & Pen ch 31 \\
\hline $\begin{array}{l}\text { Kunitz Trypsin inhibitor } \\
\text { (AF003) }\end{array}$ & Ani s 1 & $\begin{array}{l}\text { Gly m TI, Sola t2, Sola } \\
\text { t3, Sola t4 }\end{array}$ & Bos d 3, Bos d TI (aprotinin) & - \\
\hline
\end{tabular}

As can be seen from this table, there currently appear to be no known non-helminth allergens corresponding to the nematode polyprotein family, although similar biological lipid binding functions are found, e.g., in the lipocalin allergen family (AF015).

${ }^{a} \mathrm{~N}$-terminal domain similar to C-terminal domain of glutathione S-transferase (AF010).
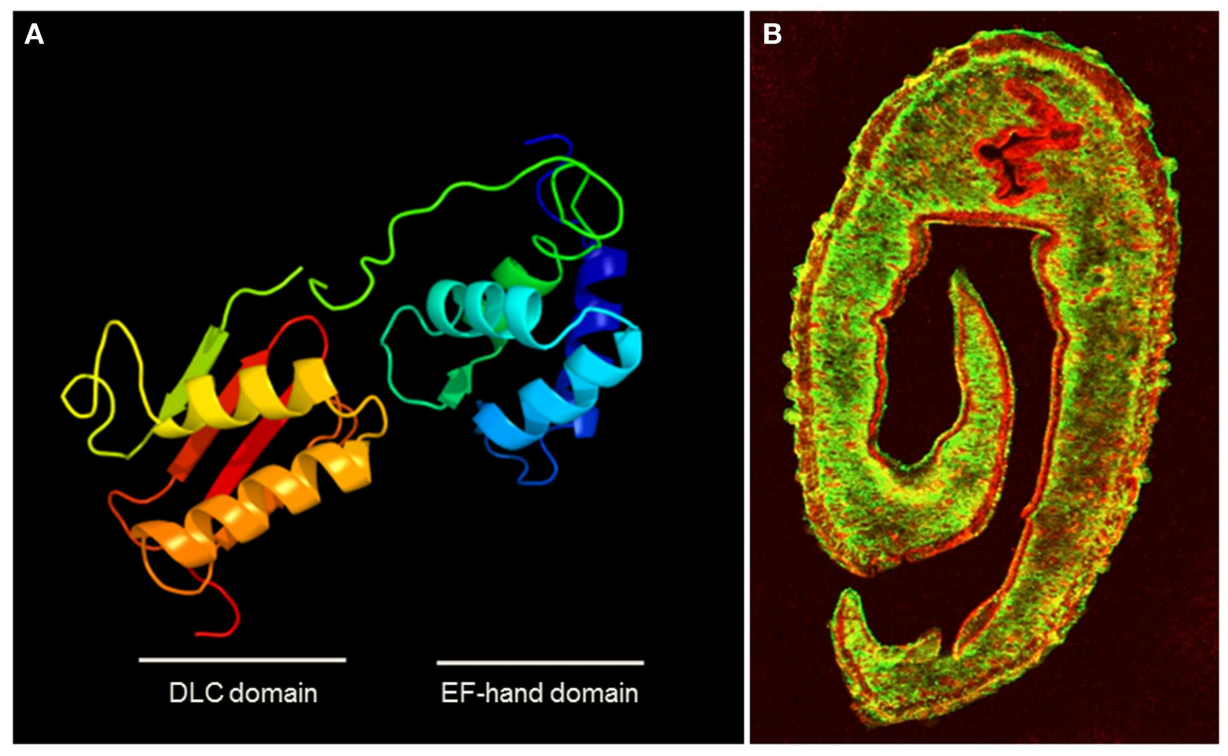

FIGURE 1 | (A) Homology modeling of the structure of the dominant SmTAL1 allergen in S. mansoni generated using protein homology/analogy recognition engine 2 (PHYRE2) (132), showing the two helix-loop-helix $\mathrm{Ca}^{2+}$-binding motifs within the EF-hand domain. (B) Transverse section of male S. mansoni worm stained for the surface protein SmCD59 (green) and under that in the tegument layer, the EF-hand protein SmTAL1 (red) (courtesy of Prof. Alan Wilson University of York). The walls of the gut also stain for SmTAL1. The location illustrates how this sub-surface allergen in inaccessible to host IgE, unless the tegument layer is damaged, but its physiological function and role in host protection remain to be elucidated. 
species that are known to be targeted by IgE during infection, other common allergen families (profilin, trypsin-like serine proteases, and lipocalin) have been identified in helminths, but their IgE binding has not yet been tested (96). Furthermore, the plant prolamins (AF050) and expansins (AF093 and AF094) are Top 10 allergen families that do not contain helminth equivalents. However, this assessment is made on sequence alignment and it is possible that these plant proteins share conformational motifs formed by non-homologous sequences (mimetopes) in un-related proteins from metazoan parasites. There is some evidence for this in that the plant expansin Php p 1 has no sequence homology with the mite allergen Der p 2, but Phl p 1, and Der p 2 have domains that share function (carbohydrate-binding) and close $3 \mathrm{D}$ conformational homology (97). While dust-mites are not metazoan parasites, they have close relatives that are (e.g., the scabies mite, Sarcoptes scabiei). Interestingly, the IgE response to Sarcoptes scabiei is thought to be involved in protection against repeat infestation (98).

\section{WHAT MAKES AN ANTIGEN AN ALLERGEN?}

Perhaps the greatest unanswered question in allergy is why only a small minority of antigens has allergenic properties. As stated previously, most proteins are not allergens. Thus, there are currently almost 15,000 protein domain families in the Pfam database (http://pfam.sanger.ac.uk/) of which only 255 have been identified in allergens (http://www.meduniwien.ac.at/allergens/allfam). The debate about which functional and molecular properties make a protein an allergen has continued for some time (99-101). Some functional properties give environmental and food proteins, a greater chance of sensitizing susceptible individuals. For example, high thermal stability allows allergens to persist in the environment or survive cooking and digestion. This is well illustrated by the example of plant chitinases, which are members of the pathogenesis-related family of proteins 4 (PR-4). Plant chitinases (AF041) have been described as panallergens in latex-fruit syndrome and are contained in a multitude of plants, such as Heveine [in latex, (102), kiwi fruit (103), in avocado (Pers a1, (104)] or grapes (105) and are related to dust-mite allergens Der p 15 and Der p 18 (106). Consistently with the hypothesis of thermal stability, despite the ubiquitousness of such PR-4 group proteins across the plant kingdom, allergenicity is only reported in foods that are consumed uncooked, as type I chitinases are inactivated by heating (107). While chitinases are also well represented in non-parasitic as well as parasitic helminths, to the best of our knowledge, no helminthic chitinases have yet been reported as allergens. The reasons for this are not understood.

In relation to food allergens and cooking, the special case of Anisakis simplex (A. simplex) deserves to be mentioned. Anisakis is the only currently known case of an organism being both a helminth parasite and a food allergen. The L3 larvae of the marine nematode $A$. simplex infect fish and cephalopods and consequently people that consume under-cooked seafood, however humans are a non-permissive host and the parasites cannot continue their life-cycle in man. Exposure to this helminth through food has been associated with allergic symptoms; asthma, rhinitis, dermatitis, and conjunctivitis (80), and in the case of uncooked fish, epigastric pain, erythema wheals, and pruritus ("gastroallergic anisakiasis"). It is not clear whether initial sensitization requires live parasite infection (anisakiasis) but it has been shown that sensitized patients can respond to heated or frozen Anisakis antigens in their food (108) or to small quantities by other exposure routes (109), such as skin contact, inhalation, or during skin prick testing. That the immune system responds to Anisakis as an invading helminth and as an allergen suggests that these are two aspects of the same response.

A feature of a relatively small subset of allergens is their proteolytic activity, which may permit penetration of mucosal barriers (110), for example, by cleaving proteins involved in tight junction formation (111). Many helminthic parasites rely on production of proteases during tissue migration, and we have previously argued that such proteases may be a factor underlying the parasites' intrinsic allergenicity (112).

However, such biological properties are not always present in allergens and the small percentage of protein domains that are targeted by IgE overall, in the absence of common biological activities, suggests they contain structures that are inherently allergenic. These structures vary widely and appear to have little in common overall. Given the probable evolution of the IgE system, we have proposed that proteins have inherent allergenicity because they have structural similarity to dominant antigens in metazoan parasites (96). However, it still remains unclear how such intrinsic structural features selectively enable a subset of antigens to induce, or become the object of, an IgE response.

Another consideration seems necessary. Many of the allergen families described above are also present in humans, but are not the target of an IgE response. Following in silico analysis of animal food proteins and their IgE responses, Jenkins and colleagues proposed that proteins with a sequence identity to a human homolog of $>62 \%$ were rarely allergenic (113). We believe the IgE system evolved to target Th2 responses at large multi-cellular parasites, organisms that are much more closely related to us that bacterial, fungal, or viral pathogens. This means the evolved molecular targets had to be restricted if foreign metazoan antigens were to be targeted without inducing tolerance or risking auto-reactivity, and that non-parasitic proteins are allergenic because of their homology with metazoan parasites.

The hypothesis was examined by Santiago et al. (114). Using a bioinformatic approach, they compared the sequences of 499 allergens against the predicted proteomes of four helminths (including Schistosoma mansoni), four bacterial, and three fungal species. Their analysis supported previous work by Emanuelsson and Spangfort (115) finding little homology between bacterial proteins and allergens and the work by Jenkins et al. (113) who showed a drop in allergenicity as homology with human equivalents increased. While they reported that over 200 allergens had homologs in helminths, this was the minority, and indeed those with the greatest homology were the least allergenic. They concluded that allergenicity does not depend on similarity with parasite proteins, but on dissimilarity with human proteins. It should be remembered however, that most IgE epitopes are probably conformational (discontinuous) $(116,117)$ and would not be identified in such primary sequence comparisons. 


\section{LIFE-CYCLE EXPRESSION OF HELMINTH ALLERGENS AND THE HOST RESPONSE}

Clinically important helminths often have complex life-cycles. Many involve a definitive host ( $\mathrm{man}$ ) and one or more intermediate hosts. The life-cycle expression profile of allergen-like molecules influences the host response. For example, trematodes (flukes) such as schistosomes undergo asexual reproduction in snail species before releasing larvae that infect humans, which then develop into adult worms that produce eggs following sexual reproduction. Some of the schistosome allergen-like TAL proteins are developmentally transcribed (22). SmTAL1 is sequestered inside the adult worms (Figure 1B) and is only exposed on the rare occasions when the adults die (56). Typically, S. mansoni worms live for 79 years (118). As individuals are usually infected more than once, resulting in asynchronous development and death of the parasite, this resembles seasonal allergen stimulation and infected people in areas endemic for S. mansoni have high levels of IgE to SmTAL1. SmTAL2 is expressed in schistosome eggs. In chronic infection hundreds of parasite eggs are trapped and die in the tissue every day. In a process that resembles specific allergen immunotherapy (SIT), the IgE response to allergen-like SmTAL2 appears to be desensitized by the continuous exposure to small doses of the antigen, while the specific IgG4 response becomes pronounced (56). SmTAL6 is only expressed in the snail stage and has no effect on the human response (119).

Adult tapeworms live in the lumen of the gut shedding eggs for excretion. If these eggs are ingested by a secondary host, they hatch and larvae encyst in the soft tissue. The contents of these structures are highly allergenic and can cause anaphylaxis if they burst. People carrying cysts of Echinococcus granulosus (echinococcosis) have IgE to parasite antigens $\mathrm{AgB}$, a protease inhibitor, $\mathrm{Ag} 5$, a serine protease, and EA21 $(65,67)$. EA21 is a cyclophilin that shares close homology with allergenic yeast cyclophilin (Mal f 6) and may be cross-reactive with allergenic birch cyclophilin Bet $\mathrm{v}$ 7 (65). Infected individuals also produce IgE to the C-terminal region of E. granulosus Heat Shock Protein 70 an antigen with close homology to the dust-mite allergen, Der f HSP70 (68).

Hookworm eggs hatch in the soil where the larvae undergo several molts before becoming the infectious $\mathrm{L} 3$ form that penetrates the skin of the foot. The larvae then migrate to the lung and are coughed up, swallowed, and hence taken to their niche in the small intestine. It is the skin-penetrating L3 form that expresses and secretes the VAL protein ASP-2 (120). Since an antibody response to the molecule was associated with reduced infection ASP-2 has been tested as a vaccine candidate (24). Unfortunately, clinical trials in a hookworm endemic region of Brazil had to be stopped when vaccinated volunteers with a probable previous history of infection (as judged by the levels of pre-vaccination parasitespecific IgE) developed symptoms of generalized urticaria (84). The relationship between the protective effects of parasite-specific IgE and the hazards of vaccinating a sensitized population with an allergen present a major conundrum which is currently hampering the development of anti-helminthic vaccinations.

These three examples were chosen to illustrate the concept that allergen expression in helminth parasites is not a generalized feature of parasitic worms but a specific property of distinct developmental phases in the human host which is tightly linked to host protective mechanisms. Anti-protein IgE responses and host defense are two sides of the same coin which in our opinion are inseparable from each other.

However, while the link between the presence of parasitespecific IgE and resistance to infection is well supported by epidemiological and experimental evidence, the detailed molecular basis underlying such resistance is less well understood.

Specifically, one of the great unanswered questions is whether the presence of IgE on FceRI-carrying cells (mainly basophils, mast cells, eosinophils) and subsequent receptor cross-linking by parasitic allergens is needed for host protection. Is the activation of basophils, mast cells, and other IgE-bearing effector cells necessary for protection?

It is well know that activation of mast cells and eosinophils can release proteases and toxic proteins (chymase, tryptase, major basic protein, eosinophil-derived neurotoxin, eosinophils cationic protein, etc.), some of which have been shown to directly kill larval stages of parasites (121).

Similarly, it could be speculated that IgE-dependent activation of basophils, which can result in the release of preformed or de novo produced highly toxic polypeptides such as Granzyme B (122) and possibly defensins (Falcone, unpublished data), also may result in parasite killing. While host-derived defensins have been shown to be effective against several unicellular parasites such as Plasmodium (123), Toxoplasma (124), Babesia (125), or Trypanosoma (126), their role in anti-helminthic immunity has only recently begun to be explored (127).

\section{A LOOK INTO THE FUTURE: "MOLECULE-BASED" ANALYSIS OF ANTI-PARASITE HOST IMMUNE RESPONSES?}

Traditionally, immunoparasitological research has relied on the use of complex antigenic mixtures such as somatic extracts of larval or adult stages, of eggs or of the tegument, or excretory/secretory materials collected in vitro, which all contain a multitude of antigens, allergens, and other un-related components. This can result in a low signal to noise ratio, for example caused by the presence of highly cross-reactive carbohydrate moieties, masking specific interactions at the individual protein level.

Due to the widespread use of complex water-soluble extracts obtained from parasitic materials in the past decades of parasitology research, several questions still remain to be answered. What are the individual molecular targets of the protective IgE response? Are certain patterns of IgE reactivity (rather than against a single determinant) associated with host protection? Do different IgE reactivity patterns correlate with various degrees of resistance to infection or post treatment re-infection?

This is reminiscent of the situation previously encountered in allergy research, which relied on water-soluble extracts which are difficult to standardize for diagnostic purposes (128), and may contain interfering components. Major impulses in the past years have come from introducing component resolved diagnosis (CRD) to the study of human allergy. In CRD, individual recombinant or purified allergens are used for measurement of immunoglobulin responses in allergic individuals (129). This frequently takes advantage of the availability of protein microarrays 
(130). One of the key advantages of CRD is that it may enable distinction between genuine $\operatorname{IgE}$ reactivity and cross-reactive IgE (131).

While the use of CRD in allergy diagnosis is conceptually slightly different (it is used to identify the allergen source when cross-reactive allergen components are present), we suggest that a similar "molecule-based" approach would allow a better understanding of host resistance against helminths at the molecular level and, from a practical point of view, point the way to safer or more effective multi-target anti-helminthic vaccinations.

\section{CONCLUDING REMARIS}

If the IgE axis evolved to protect mammals against multi-cellular parasites, studying host responses to these organisms may teach us much about other IgE-mediated phenomena such as allergy. For example, characterizing parasite structures targeted by IgE may identify homologous molecules and potential allergens in novel foods and genetically modified organisms. The relationship between allergy and helminth infection brings costs and benefits. Elucidation of the molecular mechanisms by which some parasites moderate Th2 response in their hosts, may yield improved therapy for allergic conditions. On the other hand, treatment for the same worms in the developing world may inadvertently increase the prevalence of atopic disease. Moreover as a consequence of crossreactivity between parasite and environmental allergens certain helminths can actually sensitize and aggravate allergy. Parasitic worm infections are a serious health problem in many countries and high resolution molecular techniques developed in the allergy field may help us to understand better the anti-parasite responses that are associated with immunity.

\section{ACKNOWLEDGMENTS}

The work described in this publication was supported by the Wellcome Trust via program (ref. number WT 083931/Z/07/Z) and project (ref. number WT 094317/Z/10/Z) grants.

\section{REFERENCES}

1. Allen JE, Maizels RM. Diversity and dialogue in immunity to helminths. Nat Rev Immunol (2011) 11:375-88. doi:10.1038/nri2992

2. Artis D, Maizels RM, Finkelman FD. Forum: immunology: allergy challenged. Nature (2012) 484(7395):458-9. doi:10.1038/484458a

3. Johansson SG, Hourihane JO, Bousquet J, Bruijnzeel-Koomen C, Dreborg S, Haahtela T, et al. A revised nomenclature for allergy. An EAACI position statement from the EAACI nomenclature task force. Allergy (2001) 56:813-24. doi:10.1111/j.1398-9995.2001.00002.x-i1

4. Steinke JW, Rich SS, Borish L. Genetics of allergic disease. J Allergy Clin Immunol (2008) 121(2 Suppl):S384-7. doi:10.1016/j.jaci.2007.07.029

5. Potaczek DP, Nishiyama C, Sanak M, Szczeklik A, Okumura K. Genetic variability of the high-affinity IgE receptor alpha-subunit (FcepsilonRIalpha). Immunol Res (2009) 45:75-84. doi:10.1007/s12026-008-8042-0

6. Zhu N, Gong Y, Chen X, Zhang J, Long F, He J, et al. Association between the polymorphisms of interleukin-4, the interleukin-4 receptor gene and asthma. Chin Med J (Engl) (2013) 126:2943-51.

7. Casaca VI, Illi S, Klucker E, Ballenberger N, Schedel M, von Mutius E, et al. STAT6 polymorphisms are associated with neonatal regulatory $\mathrm{T}$ cells and cytokines and atopic diseases at 3 years. Allergy (2013) 68:1249-58. doi:10.1111/all.12220

8. McSorley HJ, Maizels RM. Helminth infections and host immune regulation. Clin Microbiol Rev (2012) 25(4):585-608. doi:10.1128/CMR.05040-11

9. Palm NW, Rosenstein RK, Medzhitov R. Allergic host defences. Nature (2012) 484:465-72. doi:10.1038/nature11047
10. Profet M. The function of allergy: immunological defense against toxins. $Q$ Rev Biol (1991) 66:23-62. doi:10.1086/417049

11. Portier P, Richet C. De l'action anaphylactique de certain venins. C R Soc Bio (1902) 54:170-2.

12. Blank U, Falcone FH, Nilsson G. The history of mast cell and basophil researchsome lessons learnt from the last century. Allergy (2013) 68:1093-101. doi:10.1111/all.12197

13. Paveley RA, Aynsley SA, Cook PC, Turner JD, Mountford AP. Fluorescent imaging of antigen released by a skin-invading helminth reveals differential uptake and activation profiles by antigen presenting cells. PLoS Negl Trop Dis (2009) 3:e528. doi:10.1371/journal.pntd.0000528

14. Obata-Ninomiya K, Ishiwata K, Tsutsui H, Nei Y, Yoshikawa S, Kawano Y, et al. The skin is an important bulwark of acquired immunity against intestinal helminths. J Exp Med (2013) 210:2583-95. doi:10.1084/jem.20130761

15. Degen WGJ, Daal N, van Rothwell L, Kaiser P, Schijns VEJC. Th1/Th2 polarization by viral and helminth infection in birds. Vet Microbiol (2005) 105:163-7. doi:10.1016/j.vetmic.2004.12.001

16. Rihet P, Demeure CE, Bourgois A, Prata A, Dessein AJ. Evidence for an association between human resistance to Schistosoma mansoni and high anti-larval IgE levels. Eur J Immunol (1991) 21:2679-86. doi:10.1002/eji. 1830211106

17. Hagan P, Blumenthal UJ, Dunn D, Simpson AJ, Wilkins HA. Human IgE, IgG4 and resistance to reinfection with Schistosoma haematobium. Nature (1991) 349:243-5. doi:10.1038/349243a0

18. Dunne DW, Butterworth AE, Fulford AJ, Kariuki HC, Langley JG, Ouma $\mathrm{JH}$, et al. Immunity after treatment of human schistosomiasis: association between $\operatorname{IgE}$ antibodies to adult worm antigens and resistance to reinfection. Eur J Immunol (1992) 22:1483-94. doi:10.1002/eji.1830220622

19. Dunne DW, Webster M, Smith P, Langley JG, Richardson BA, Fulford AJ, et al. The isolation of a $22 \mathrm{kDa}$ band after SDS-PAGE of Schistosoma mansoni adult worms and its use to demonstrate that IgE responses against the antigen(s) it contains are associated with human resistance to reinfection. Parasite Immunol (1997) 19:79-89. doi:10.1046/j.1365-3024.1997.d01-186.x

20. Jiz M, Friedman JF, Leenstra T, Jarilla B, Pablo A, Langdon G, et al. Immunoglobulin $\mathrm{E}(\mathrm{IgE})$ responses to paramyosin predict resistance to reinfection with Schistosoma japonicum and are attenuated by IgG4. Infect Immun (2009) 77:2051-8. doi:10.1128/IAI.00012-09

21. Pinot de Moira A, Fulford AJC, Kabatereine NB, Ouma JH, Booth M, et al. Analysis of complex patterns of human exposure and immunity to Schistosomiasis mansoni: the influence of age, sex, ethnicity and IgE. PLoS Negl Trop Dis (2010) 4:e820. doi:10.1371/journal.pntd.0000820

22. Fitzsimmons CM, Jones FM, Pinot de Moira A, Protasio AV, Khalife J, Dickinson HA, et al. Progressive cross-reactivity in IgE responses: an explanation for the slow development of human immunity to schistosomiasis? Infect Immun (2012) 80:4264-70. doi:10.1128/IAI.00641-12

23. Pritchard DI, Quinnell RJ, Walsh EA. Immunity in humans to Necator americanus: IgE, parasite weight and fecundity. Parasite Immunol (1995) 17:71-5. doi:10.1111/j.1365-3024.1995.tb00968.x

24. Bethony J, Loukas A, Smout M, Brooker S, Mendez S, Plieskatt J, et al. Antibodies against a secreted protein from hookworm larvae reduce the intensity of hookworm infection in humans and vaccinated laboratory animals. FASEB $J$ (2005) 19:1743-5.

25. Faulkner H, Turner J, Kamgno J, Pion SD, Boussinesq M, Bradley JE. Ageand infection intensity-dependent cytokine and antibody production in human trichuriasis: the importance of IgE. J Infect Dis (2002) 185:665-72. doi: $10.1086 / 339005$

26. McSharry C, Xia Y, Holland CV, Kennedy MW. Natural immunity to Ascaris lumbricoides associated with immunoglobulin $\mathrm{E}$ antibody to ABA-1 allergen and inflammation indicators in children. Infect Immun (1999) 67:484-9.

27. Turner JD, Faulkner H, Kamgno J, Kennedy MW, Behnke J, Boussinesq M, et al. Allergen-specific IgE and IgG4 are markers of resistance and susceptibility in a human intestinal nematode infection. Microbes Infect Inst Pasteur (2005) 7:990-6. doi:10.1016/j.micinf.2005.03.036

28. Falcone FH, Telford G, Hooi D, Brown AP, Seabra R, Feary J, et al. Antigendriven basophil activation is indicative of early Necator americanus infection in IgE-seronegative patients. J Allergy Clin Immunol (2009) 124:1343.e-50.e. doi:10.1016/j.jaci.2009.07.039

29. Pearce N, Aït-Khaled N, Beasley R, Mallol J, Keil U, Mitchell E, et al. Worldwide trends in the prevalence of asthma symptoms: phase III of the 
International Study of Asthma and Allergies in Childhood (ISAAC). Thorax (2007) 62:758-66. doi:10.1136/thx.2006.070169

30. Rook GAW. Review series on helminths, immune modulation and the hygiene hypothesis: the broader implications of the hygiene hypothesis. Immunology (2009) 126:3-11. doi:10.1111/j.1365-2567.2008.03007.x

31. van den Biggelaar AH, van Ree R, Rodrigues LC, Lell B, Deelder AM, Kremsner PG, et al. Decreased atopy in children infected with Schistosoma haematobium: a role for parasite-induced interleukin-10. Lancet (2000) 356:1723-7. doi:10.1016/S0140-6736(00)03206-2

32. Cooper PJ, Chico ME, Rodrigues LC, Ordonez M, Strachan D, Griffin GE, et al. Reduced risk of atopy among school-age children infected with geohelminth parasites in a rural area of the tropics. J Allergy Clin Immunol (2003) 111:995-1000. doi:10.1067/mai.2003.1348

33. Rodrigues LC, Newcombe PJ, Cunha SS, Alcantara-Neves NM, Genser B, Cruz AA, et al. Early infection with Trichuris trichiura and allergen skin test reactivity in later childhood. Clin Exp Allergy (2008) 38:1769-77. doi:10.1111/j.13652222.2008.03027.x

34. Leonardi-Bee J, Pritchard D, Britton J. Asthma and current intestinal parasite infection: systematic review and meta-analysis. Am J Respir Crit Care Med (2006) 174:514-23. doi:10.1164/rccm.200603-331OC

35. Scrivener S, Yemaneberhan H, Zebenigus M, Tilahun D, Girma S, Ali S, et al. Independent effects of intestinal parasite infection and domestic allergen exposure on risk of wheeze in Ethiopia: a nested case-control study. Lancet (2001) 358:1493-9. doi:10.1016/S0140-6736(01)06579-5

36. Flohr C, Tuyen LN, Quinnell RJ, Lewis S, Minh TT, Campbell J, et al. Reduced helminth burden increases allergen skin sensitization but not clinical allergy: a randomized, double-blind, placebo-controlled trial in Vietnam. Clin Exp Allergy (2010) 40:131-42. doi:10.1111/j.1365-2222.2009.03346.x

37. Feary JR, Venn AJ, Mortimer K, Brown AP, Hooi D, Falcone FH, et al. Experimental hookworm infection: a randomized placebo-controlled trial in asthma. Clin Exp Allergy (2010) 40:299-306. doi:10.1111/j.1365-2222.2009. 03433.x

38. Lynch NR, Hagel I, Perez M, Di Prisco MC, Lopez R, Alvarez N. Effect of anthelmintic treatment on the allergic reactivity of children in a tropical slum. J Allergy Clin Immunol (1993) 92:404-11. doi:10.1016/0091-6749(93) 90119-Z

39. van den Biggelaar AHJ, Rodrigues LC, van Ree R, van der Zee JS, HoeksmaKruize YCM, Souverijn JHM, et al. Long-term treatment of intestinal helminths increases mite skin-test reactivity in Gabonese schoolchildren. J Infect Dis (2004) 189:892-900. doi:10.1086/381767

40. Flohr C, Quinnell RJ, Britton J. Do helminth parasites protect against atopy and allergic disease? Clin Exp Allergy (2009) 39:20-32. doi:10.1111/j.13652222.2008.03134.x

41. Wördemann M, Diaz RJ, Heredia LM, Collado Madurga AM, Ruiz Espinosa A, Prado RC, et al. Association of atopy, asthma, allergic rhinoconjunctivitis, atopic dermatitis and intestinal helminth infections in Cuban children. Trop Med Int Health (2008) 13:180-6. doi:10.1111/j.1365-3156.2007. 01988.x

42. Hagel I, Cabrera M, Hurtado MA, Sanchez P, Puccio F, Di Prisco MC, et al. Infection by Ascaris lumbricoides and bronchial hyper reactivity: an outstanding association in Venezuelan school children from endemic areas. Acta Trop (2007) 103:231-41. doi:10.1016/j.actatropica.2007.06.010

43. Radauer C, Bublin M, Wagner S, Mari A, Breiteneder H. Allergens are distributed into few protein families and possess a restricted number of biochemical functions. J Allergy Clin Immunol (2008) 121:847.e-52.e. doi:10.1016/j.jaci. 2008.01.025

44. Moneo I, Caballero ML, Gómez F, Ortega E, Alonso MJ. Isolation and characterization of a major allergen from the fish parasite Anisakis simplex. J Allergy Clin Immunol (2000) 106(Pt 1):177-82. doi:10.1067/mai.2000.106732

45. Pérez-Pérez J, Fernández-Caldas E, Marañón F, Sastre J, Bernal ML, Rodríguez $\mathrm{J}$, et al. Molecular cloning of paramyosin, a new allergen of Anisakis simplex. Int Arch Allergy Immunol (2000) 123:120-9. doi:10.1159/000024442

46. Asturias JA, Eraso E, Moneo I, Martínez A. Is tropomyosin an allergen in Anisakis? Allergy (2000) 55:898-9. doi:10.1034/j.1398-9995.2000.00734.x

47. Moneo I, Caballero ML, González-Muñoz M, Rodríguez-Mahillo AI, Rodríguez-Perez R, Silva A. Isolation of a heat-resistant allergen from the fish parasite Anisakis simplex. Parasitol Res (2005) 96:285-9. doi:10.1007/s00436005-1362-2
48. Kobayashi Y, Ishizaki S, Shimakura K, Nagashima Y, Shiomi K. Molecular cloning and expression of two new allergens from Anisakis simplex. Parasitol Res (2007) 100:1233-41. doi:10.1007/s00436-006-0396-4

49. Rodríguez E, Anadón AM, García-Bodas E, Romarís F, Iglesias R, Gárate T, et al. Novel sequences and epitopes of diagnostic value derived from the Anisakis simplex Ani s 7 major allergen. Allergy (2008) 63:219-25. doi:10.1111/j.13989995.2007.01564.x

50. Rodriguez-Perez R, Moneo I, Rodriguez-Mahillo A, Caballero ML. Cloning and expression of Ani s 9, a new Anisakis simplex allergen. Mol Biochem Parasitol (2008) 159:92-7. doi:10.1016/j.molbiopara.2008.02.008

51. Caballero ML, Umpierrez A, Moneo I, Rodriguez-Perez R. Ani s 10, a new Anisakis simplex allergen: cloning and heterologous expression. Parasitol Int (2011) 60:209-12. doi:10.1016/j.parint.2011.01.003

52. Kobayashi Y, Ohsaki K, Ikeda K, Kakemoto S, Ishizaki S, Shimakura K, et al. Identification of novel three allergens from Anisakis simplex by chemiluminescent immunoscreening of an expression cDNA library. Parasitol Int (2011) 60:144-50. doi:10.1016/j.parint.2011.01.004

53. López I, Pardo MA. A phage display system for the identification of novel Anisakis simplex antigens. J Immunol Methods (2011) 373:247-51. doi:10.1016/ j.jim.2011.08.009

54. Arrieta I, del Barrio M, Vidarte L, del Pozo V, Pastor C, Gonzalez-Cabrero $\mathrm{J}$, et al. Molecular cloning and characterization of an IgE-reactive protein from Anisakis simplex: Ani s 1. Mol Biochem Parasitol (2000) 107:263-8. doi:10.1016/S0166-6851(00)00192-4

55. Webster M, Correa-Oliveira R, Gazzinelli G, Viana IR, Fraga LA, Silveira AM, et al. Factors affecting high and low human IgE responses to schistosome worm antigens in an area of Brazil endemic for Schistosoma mansoni and hookworm. Am J Trop Med Hyg (1997) 57:487-94.

56. Fitzsimmons CM, McBeath R, Joseph S, Jones FM, Walter K, Hoffmann KF, et al. Factors affecting human IgE and IgG responses to allergen-like Schistosoma mansoni antigens: molecular structure and patterns of in vivo exposure. Int Arch Allergy Immunol (2007) 142:40-50. doi:10.1159/000095997

57. Webster M, Fulford AJ, Braun G, Ouma JH, Kariuki HC, Havercroft JC, et al. Human immunoglobulin E responses to a recombinant 22.6-kilodalton antigen from Schistosoma mansoni adult worms are associated with low intensities of reinfection after treatment. Infect Immun (1996) 64:4042-6.

58. de Oliveira Fraga LA, Lamb EW, Moreno EC, Chatterjee M, Dvorák J, Delcroix M, et al. Rapid induction of IgE responses to a worm cysteine protease during murine pre-patent schistosome infection. BMC Immunol (2010) 11:56. doi:10.1186/1471-2172-11-56

59. Schramm G, Hamilton JV, Balog CI, Wuhrer M, Gronow A, Beckmann S, et al. Molecular characterisation of kappa-5, a major antigenic glycoprotein from Schistosoma mansoni eggs. Mol Biochem Parasitol (2009) 166:4-14. doi:10.1016/j.molbiopara.2009.02.003

60. Zhan B, Santiago H, Keegan B, Gillespie P, Xue J, Bethony J, et al. Fusion of Na-ASP-2 with human immunoglobulin Fc $\gamma$ abrogates histamine release from basophils sensitized with anti-Na-ASP-2 IgE. Parasite Immunol (2012) 34:404-11. doi:10.1111/j.1365-3024.2012.01371.x

61. Pritchard DI, Brown A, Kasper G, McElroy P, Loukas A, Hewitt C, et al. A hookworm allergen which strongly resembles calreticulin. Parasite Immunol (1999) 21:439-50. doi:10.1046/j.1365-3024.1999.00238.x

62. Christie JF, Dunbar B, Kennedy MW. The ABA-1 allergen of the nematode Ascaris suum: epitope stability, mass spectrometry, and $\mathrm{N}$-terminal sequence comparison with its homologue in Toxocara canis. Clin Exp Immunol (1993) 92:125-32. doi:10.1111/j.1365-2249.1993.tb05958.x

63. Acevedo N, Sánchez J, Erler A, Mercado D, Briza P, Kennedy M, et al. IgE cross-reactivity between Ascaris and domestic mite allergens: the role of tropomyosin and the nematode polyprotein ABA-1. Allergy (2009) 64:1635-43. doi:10.1111/j.1398-9995.2009.02084.x

64. Acevedo N, Mohr J, Zakzuk J, Samonig M, Briza P, Erler A, et al. Proteomic and Immunochemical characterization of glutathione transferase as a new allergen of the nematode Ascaris lumbricoides. PLoS One (2013) 8:e78353. doi:10.1371/journal.pone.0078353

65. Vuitton DA. Echinococcosis and allergy. Clin Rev Allergy Immunol (2004) 26:93-104. doi:10.1007/s12016-004-0004-2

66. Khabiri AR, Bagheri F, Assmar M, Siavashi MR. Analysis of specific IgE and IgG subclass antibodies for diagnosis of Echinococcus granulosus. Parasite Immunol (2006) 28:357-62. doi:10.1111/j.1365-3024.2006.00837.x 
67. Ortona E, Vaccari S, Margutti P, Delunardo F, Rigano R, Profumo E, et al. Immunological characterization of Echinococcus granulosus cyclophilin, an allergen reactive with IgE and IgG4 from patients with cystic echinococcosis. Clin Exp Immunol (2002) 128:124-30. doi:10.1046/j.1365-2249.2002.01807.x

68. Ortona E, Margutti P, Delunardo F, Vaccari S, Riganò R, Profumo E, et al. Molecular and immunological characterization of the C-terminal region of a new Echinococcus granulosus Heat Shock Protein 70. Parasite Immunol (2003) 25:119-26. doi:10.1046/j.1365-3024.2003.00617.x

69. Ortona E, Margutti P, Vaccari S, Riganò R, Profumo E, Buttari B, et al. Elongation factor 1 beta/delta of Echinococcus granulosus and allergic manifestations in human cystic echinococcosis. Clin Exp Immunol (2001) 125:110-6. doi:10.1046/j.1365-2249.2001.01569.x

70. Sereda MJ, Hartmann S, Büttner DW, Volkmer R, Hovestädt M, Brattig N, et al. Characterization of the allergen filarial tropomyosin with an invertebrate specific monoclonal antibody. Acta Trop (2010) 116:61-7. doi:10.1016/j. actatropica.2010.05.010

71. Rathaur S, Fischer P, Domagalski M, Walter RD, Liebau E. Brugia malayi and Wuchereria bancrofti: gene comparison and recombinant expression of pi-class related glutathione S-transferases. Exp Parasitol (2003) 103:177-81. doi:10.1016/S0014-4894(03)00093-6

72. Krushna NSA, Shiny C, Dharanya S, Sindhu A, Aishwarya S, Narayanan RB. Immunolocalization and serum antibody responses to Brugia malayi pepsin inhibitor homolog (Bm-33). Microbiol Immunol (2009) 53:173-83. doi:10.1111/j.1348-0421.2009.00114.x

73. Mari A, Rasi C, Palazzo P, Scala E. Allergen databases: current status and perspectives. Curr Allergy Asthma Rep (2009) 9:376-83. doi:10.1007/s11882-0090055-9

74. Marchler-Bauer A, Zheng C, Chitsaz F, Derbyshire MK, Geer LY, Geer RC, et al. CDD: conserved domains and protein three-dimensional structure. Nucleic Acids Res (2013) 41:D348-52. doi:10.1093/nar/gks1243

75. Punta M, Coggill PC, Eberhardt RY, Mistry J, Tate J, Boursnell C, et al. The Pfam protein families database. Nucleic Acids Res (2012) 40:D290-301. doi:10.1093/nar/gkr1065

76. Jenkins RE, Taylor MJ, Gilvary NJ, Bianco AE. Tropomyosin implicated in host protective responses to microfilariae in onchocerciasis. Proc Natl Acad Sci USA (1998) 95:7550-5. doi:10.1073/pnas.95.13.7550

77. Santiago HC, Bennuru S, Boyd A, Eberhard M, Nutman TB. Structural and immunologic cross-reactivity among filarial and mite tropomyosin: implications for the hygiene hypothesis. J Allergy Clin Immunol (2011) 127:479-86. doi:10.1016/j.jaci.2010.11.007

78. Santos ABR, Rocha GM, Oliver C, Ferriani VPL, Lima RC, Palma MS, et al. Cross-reactive IgE antibody responses to tropomyosins from Ascaris lumbricoides and cockroach. J Allergy Clin Immunol (2008) 121:1040.e-6.e. doi:10.1016/j.jaci.2007.12.1147

79. Valmonte GR, Cauyan GA, Ramos JDA. IgE cross-reactivity between house dust mite allergens and Ascaris lumbricoides antigens. Asia Pac Allergy (2012) 2:35-44. doi:10.5415/apallergy.2012.2.1.35

80. Nieuwenhuizen NE, Lopata AL. Anisakis - a food-borne parasite that triggers allergic host defences. Int J Parasitol (2013) 43:1047-57. doi:10.1016/j.ijpara. 2013.08.001

81. Steel C, Limberger RJ, McReynolds LA, Ottesen EA, Nutman TB. B cell responses to paramyosin. Isotypic analysis and epitope mapping of filarial paramyosin in patients with onchocerciasis. J Immunol (1990) 145: 3917-23.

82. Kucik CJ, Martin GL, Sortor BV. Common intestinal parasites. Am Fam Physician (2004) 69:1161-8.

83. Guarneri F, Guarneri C, Benvenga S. Cross-reactivity of Anisakis simplex: possible role of Ani s 2 and Ani s 3. Int J Dermatol (2007) 46:146-50.

84. Diemert DJ, Pinto AG, Freire J, Jariwala A, Santiago H, Hamilton RG, et al. Generalized urticaria induced by the Na-ASP-2 hookworm vaccine: implications for the development of vaccines against helminths. JAllergy Clin Immunol (2012) 130:169.e-76.e. doi:10.1016/j.jaci.2012.04.027

85. Tawe W, Pearlman E, Unnasch TR, Lustigman S. Angiogenic activity of Onchocerca volvulus recombinant proteins similar to vespid venom antigen 5 . Mol Biochem Parasitol (2000) 109:91-9. doi:10.1016/S0166-6851(00)00231-0

86. Murray J, Gregory WF, Gomez-Escobar N, Atmadja AK, Maizels RM. Expression and immune recognition of Brugia malayi VAL-1, a homologue of vespid venom allergens and Ancylostoma secreted proteins. Mol Biochem Parasitol (2001) 118:89-96. doi:10.1016/S0166-6851(01)00374-7

87. Chalmers IW, McArdle AJ, Coulson RM, Wagner MA, Schmid R, Hirai $\mathrm{H}$, et al. Developmentally regulated expression, alternative splicing and distinct sub-groupings in members of the Schistosoma mansoni venom allergen-like (SmVAL) gene family. BMC Genomics (2008) 9:89. doi:10.1186/ 1471-2164-9-89

88. Chen J, Hu X, He S, Wang L, Hu D, Wang X, et al. Expression and immune response analysis of Schistosoma japonicum VAL-1, a homologue of vespid venom allergens. Parasitol Res (2010) 106:1413-8. doi:10.1007/s00436-0101817-y

89. Tsai IJ, Zarowiecki M, Holroyd N, Garciarrubio A, Sanchez-Flores A, Brooks KL, et al. The genomes of four tapeworm species reveal adaptations to parasitism. Nature (2013) 496:57-63. doi:10.1038/nature12031

90. Farias LP, Rodrigues D, Cunna V, Rofatto HK, Faquim-Mauro EL, Leite LCC. Schistosoma mansoni venom allergen like proteins present differential allergic responses in a murine model of airway inflammation. PLoS Negl Trop Dis (2012) 6:e1510. doi:10.1371/journal.pntd.0001510

91. Subpipattana P, Grams R, Vichasri-Grams S. Analysis of a calcium-binding EF-hand protein family in Fasciola gigantica. Exp Parasitol (2012) 130:364-73. doi:10.1016/j.exppara.2012.02.005

92. Santiago HC, LeeVan E, Bennuru S, Ribeiro-Gomes F, Mueller E, Wilson M, et al. Molecular mimicry between cockroach and helminth glutathione Stransferases promotes cross-reactivity and cross-sensitization. J Allergy Clin Immunol (2012) 130:248.e-56.e. doi:10.1016/j.jaci.2012.02.045

93. Kennedy MW. The nematode polyprotein allergens/antigens. Parasitol Today (2000) 16:373-80. doi:10.1016/S0169-4758(00)01743-9

94. Paxton WA, Yazdanbakhsh M, Kurniawan A, Partono F, Maizels RM, Selkirk ME. Primary structure of and immunoglobulin E response to the repeat subunit of gp 15/400 from human lymphatic filarial parasites. Infect Immun (1993) 61:2827-33.

95. Orton SM, Arasu P, Hammerberg B. A novel gene from Brugia sp. that encodes a cytotoxic fatty acid binding protein allergen recognized by canine monoclonal IgE and serum IgE from infected dogs. J Parasitol (2007) 93:1378-87. doi:10.1645/GE-1217.1

96. Fitzsimmons CM, Dunne DW. Survival of the fittest: allergology or parasitology? Trends Parasitol (2009) 25:447-51. doi:10.1016/j.pt.2009.07.004

97. Shani N, Shani Z, Shoseyov O, Mruwat R, Shoseyov D. Oxidized cellulose binding to allergens with a carbohydrate-binding module attenuates allergic reactions. J Immunol (2011) 186:1240-7. doi:10.4049/jimmunol. 1000640

98. Tarigan S, Huntley JF. Failure to protect goats following vaccination with soluble proteins of Sarcoptes scabiei: evidence for a role for IgE antibody in protection. Vet Parasitol (2005) 133:101-9. doi:10.1016/j.vetpar.2005.03.044

99. Traidl-Hoffmann C, Jakob T, Behrendt H. Determinants of allergenicity. J Allergy Clin Immunol (2009) 123(3):558-66. doi:10.1016/j.jaci.2008.12.003

100. Bredehorst R, David K. What establishes a protein as an allergen? J Chromatogr B Biomed Sci Appl (2001) 756:33-40. doi:10.1016/S0378-4347(01)00069-X

101. Furmonaviciene R, Sutton BJ, Glaser F, Laughton CA, Jones N, Sewell HF, et al. An attempt to define allergen-specific molecular surface features: a bioinformatic approach. Bioinformatics (2005) 21:4201-4. doi:10.1093/bioinformatics/ bti700

102. Beezhold DH, Kostyal DA, Sussman GL. IgE epitope analysis of the hevein preprotein; a major latex allergen. Clin Exp Immunol (1997) 108:114-21. doi:10.1046/j.1365-2249.1997.d01-983.x

103. Bublin M, Radauer C, Knulst A, Wagner S, Scheiner O, Mackie AR, et al. Effects of gastrointestinal digestion and heating on the allergenicity of the kiwi allergens Act d 1, actinidin, and Act d 2, a thaumatin-like protein. Mol Nutr Food Res (2008) 52:1130-9. doi:10.1002/mnfr.200700167

104. Díaz-Perales A, Blanco C, Sánchez-Monge R, Varela J, Carrillo T, Salcedo G. Analysis of avocado allergen (Prs a 1) IgE-binding peptides generated by simulated gastric fluid digestion. J Allergy Clin Immunol (2003) 112:1002-7. doi:10.1016/j.jaci.2003.07.006

105. Pastorello EA, Farioli L, Pravettoni V, Ortolani C, Fortunato D, Giuffrida MG, et al. Identification of grape and wine allergens as an endochitinase 4, a lipidtransfer protein, and a thaumatin. J Allergy Clin Immunol (2003) 111:350-9. doi:10.1067/mai.2003.35 
106. O’Neil SE, Heinrich TK, Hales BJ, Hazell LA, Holt DC, Fischer K, et al. The chitinase allergens Der p 15 and Der p 18 from Dermatophagoides pteronyssinus. Clin Exp Allergy (2006) 36:831-9. doi:10.1111/j.1365-2222.2006.02497.x

107. Sánchez-Monge R, Blanco C, Perales AD, Collada C, Carrillo T, Aragoncillo $\mathrm{C}$, et al. Class I chitinases, the panallergens responsible for the latex-fruit syndrome, are induced by ethylene treatment and inactivated by heating. J Allergy Clin Immunol (2000) 106:190-5. doi:10.1067/mai.2000.107599

108. Audicana MT, Ansotegui IJ, de Corres LF, Kennedy MW. Anisakis simplex: dangerous - dead and alive? Trends Parasitol (2002) 18:20-5. doi:10.1016/S14714922(01)02152-3

109. Audicana MT, Kennedy MW. Anisakis simplex: from obscure infectious worm to inducer of immune hypersensitivity. Clin Microbiol Rev (2008) 21:360-79. doi:10.1128/CMR.00012-07

110. Herbert CA, King CM, Ring PC, Holgate ST, Stewart GA, Thompson PJ, et al. Augmentation of permeability in the bronchial epithelium by the house dust mite allergen Der pl. Am J Respir Cell Mol Biol (1995) 12:369-78. doi:10.1165/ajrcmb.12.4.7695916

111. Wan H, Winton HL, Soeller C, Tovey ER, Gruenert DC, Thompson PJ, et al. Der p 1 facilitates transepithelial allergen delivery by disruption of tight junctions. J Clin Invest (1999) 104:123-33. doi:10.1172/JCI5844

112. Falcone FH, Loukas A, Quinnell RJ, Pritchard DI. The innate allergenicity of helminth parasites. Clin Rev Allergy Immunol (2004) 26:61-72. doi:10.1385/ CRIAI:26:1:61

113. Jenkins JA, Breiteneder H, Mills ENC. Evolutionary distance from human homologs reflects allergenicity of animal food proteins. J Allergy Clin Immunol (2007) 120:1399-405. doi:10.1016/j.jaci.2007.08.019

114. Santiago H, da C, Bennuru S, Ribeiro JMC, Nutman TB. Structural differences between human proteins and aero- and microbial allergens define allergenicity. PLoS One (2012) 7:e40552. doi:10.1371/journal.pone.0040552

115. Emanuelsson C, Spangfort MD. Allergens as eukaryotic proteins lacking bacterial homologues. Mol Immunol (2007) 44:3256-60. doi:10.1016/j.molimm. 2007.01.019

116. Arnon R, Van Regenmortel MH. Structural basis of antigenic specificity and design of new vaccines. FASEB J (1992) 6:3265-74.

117. Valenta R, Ball T, Focke M, Linhart B, Mothes N, Niederberger V, et al. Immunotherapy of allergic disease. Adv Immunol (2004) 82:105-53. doi:10. 1016/S0065-2776(04)82003-0

118. Fulford AJ, Butterworth AE, Ouma JH, Sturrock RF. A statistical approach to schistosome population dynamics and estimation of the life-span of Schistosoma mansoni in man. Parasitology (1995) 110:307-16. doi:10.1017/ S0031182000080896

119. Fitzsimmons CM, Jones FM, Stearn A, Chalmers IW, Hoffmann KF, Wawrzyniak J, et al. The Schistosoma mansoni tegumental-allergen-like (TAL) protein family: influence of developmental expression on human IgE responses. PLoS Negl Trop Dis (2012) 6:e1593. doi:10.1371/journal.pntd.0001593

120. Hawdon JM, Hotez PJ. Hookworm: developmental biology of the infectious process. Curr Opin Genet Dev (1996) 6:618-23. doi:10.1016/S0959-437X(96) 80092-X

121. Hamann KJ, Barker RL, Loegering DA, Gleich GJ. Comparative toxicity of purified human eosinophil granule proteins for newborn larvae of Trichinella spiralis. J Parasitol (1987) 73:523-9. doi:10.2307/3282130

122. Tschopp CM, Spiegl N, Didichenko S, Lutmann W, Julius P, Virchow JC, et al. Granzyme B, a novel mediator of allergic inflammation: its induction and release in blood basophils and human asthma. Blood (2006) 108:2290-9. doi:10.1182/blood-2006-03-010348

123. Bell A. Antimalarial peptides: the long and the short of it. Curr Pharm Des (2011) 17:2719-31. doi:10.2174/138161211797416057

124. Tanaka T, Rahman MM, Battur B, Boldbaatar D, Liao M, Umemiya-Shirafuji $\mathrm{R}$, et al. Parasiticidal activity of human alpha-defensin-5 against Toxoplasma gondii. In vitro Cell Dev Biol Anim (2010) 46:560-5. doi:10.1007/s11626-0099271-9

125. Tsuji N, Battsetseg B, Boldbaatar D, Miyoshi T, Xuan X, Oliver JH, et al. Babesial vector tick defensin against Babesia sp. parasites. Infect Immun (2007) 75:3633-40. doi:10.1128/IAI.00256-07

126. Madison MN, Kleshchenko YY, Nde PN, Simmons KJ, Lima MF, Villalta F. Human defensin alpha-1 causes Trypanosoma cruzi membrane pore formation and induces DNA fragmentation, which leads to trypanosome destruction. Infect Immun (2007) 75:4780-91. doi:10.1128/IAI.00557-07

127. Magalhaes T, Oliveira IF, Melo-Santos MAV, Oliveira CMF, Lima CA, Ayres CFJ. Expression of defensin, cecropin, and transferrin in Aedes aegypti (Diptera: Culicidae) infected with Wuchereria bancrofti (Spirurida: Onchocercidae), and the abnormal development of nematodes in the mosquito. Exp Parasitol (2008) 120:364-71. doi:10.1016/j.exppara.2008.09.003

128. Larenas-Linnemann D, Cox LS. European allergen extract units and potency: review of available information. Ann Allergy Asthma Immunol (2008) 100:137-45. doi:10.1016/S1081-1206(10)60422-X

129. Lidholm J, Ballmer-Weber BK, Mari A, Vieths S. Component-resolved diagnostics in food allergy. Curr Opin Allergy Clin Immunol (2006) 6:234-40. doi:10.1097/01.all.0000225166.90768.d6

130. Ferrer M, Sanz ML, Sastre J, Bartra J, del Cuvillo A, Montoro J, et al. Molecular diagnosis in allergology: application of the microarray technique. J Investig Allergol Clin Immunol (2009) 19(Suppl 1):19-24.

131. Wolthers OD. Component-resolved diagnosis in pediatrics. ISRN Pediatr (2012) 2012:806920. doi:10.5402/2012/806920

132. Kelley LA, Sternberg MJ. Protein structure prediction on the Web: a case study using the Phyre server. Nat Protoc (2009) 4:363-371. doi:10.1038/nprot. 2009.2

Conflict of Interest Statement: The authors declare that the research was conducted in the absence of any commercial or financial relationships that could be construed as a potential conflict of interest.

Received: 15 November 2013; accepted: 03 February 2014; published online: 14 February 2014.

Citation: Fitzsimmons CM, Falcone FH and Dunne DW (2014) Helminth allergens, parasite-specific IgE, and its protective role in human immunity. Front. Immunol. 5:61. doi: 10.3389/fimmu.2014.00061

This article was submitted to Immunotherapies and Vaccines, a section of the journal Frontiers in Immunology.

Copyright (C) 2014 Fitzsimmons, Falcone and Dunne. This is an open-access article distributed under the terms of the Creative Commons Attribution License (CC BY). The use, distribution or reproduction in other forums is permitted, provided the original author(s) or licensor are credited and that the original publication in this journal is cited, in accordance with accepted academic practice. No use, distribution or reproduction is permitted which does not comply with these terms. 